\title{
Expression of functional recombinant rabies virus glycoprotein in Drosophila melanogaster $\mathbf{S 2}$ cells
}

\author{
Adriana Y Yokomizo ${ }^{1}$, Soraia AC Jorge ${ }^{1}$, Renato M Astray ${ }^{1}$, \\ Mariza AG Santos ${ }^{1}$, Irene Fernandes ${ }^{2}$, Orlando G Ribeiro ${ }^{3}$, \\ Denise SPQ Horton ${ }^{4}$, Aldo Tonso ${ }^{5}$ and Carlos A Pereira* 1
}

Address: ${ }^{2}$ Laboratório de Imunologia Viral, Instituto Butantan, 05503-900 São Paulo, Brasil, ${ }^{2}$ Laboratório de Imunopatologia, Instituto Butantan, 05503-900 São Paulo, Brasil, ${ }^{3}$ Laboratório de Imunogenética, Instituto Butantan, 05503-900 São Paulo, Brasil, ${ }^{4}$ Serviço de Controle de Qualidade, Instituto Butantan, 05503-900 São Paulo, Brasil and ${ }^{5}$ Departamento de Engenharia Química, Escola Politécnica, Universidade de São Paulo, Brasil

* Corresponding author

from The 4th Recombinant Protein Production Meeting: a comparative view on host physiology

Barcelona, Spain. 2I-23 September 2006

Published: 10 October 2006

Microbial Cell Factories 2006, 5(Suppl I):P89 doi:I0.II86/1475-2859-5-SI-P89

() 2006 Yokomizo et al; licensee BioMed Central Ltd.

\section{Background}

The rabies virus belongs to the genus Lyssavirus from the Rhabdoviridae family and is widely distributed in nature infecting mammals. Upon infection it can be transmitted to animals or humans and leads to a fatal disease that nowadays has no treatment. Vaccines are commercially available and prevent the disease in animals and humans. Protocols for human or veterinarian vaccine manufacturing evolved from animal tissue homogenates to cell culture technology and today recombinant viral proteins and DNA vaccines are under investigation. The evidence that rabies virus infects and can cause disease in animals and humans, being neutralized by an immune response mounted by very similar vaccines opens a great possibility of testing new vaccines first in experimental animals prior to use in humans [1].

\section{Results}

Recombinant rabies vírus glycoprotein (rGPV) was expressed in Drosophila melanogaster Schneider 2 (S2) cells. The cDNA encoding the GPV gene was cloned in expression plasmids under the control of the inducible metallothionein promoter $(\mathrm{Mt})$ or the constitutive actin promoter (Ac). These were alternatively co-transfected into S2 cells together with a hygromycin selection plasmid. Selected S2 cell populations (S2MtGPV or S2AcGPV) had a decreased ability to grow and consume substrates, when compared to the non transfected cells (S2). They were shown, by PCR, to express the GPV gene and mRNA as well as, by immunoblotting, to synthesize the rGPV in its expected molecular weight of $65 \mathrm{kDa}$. ELISA kinetic studies showed the rGPV expression in cell lysates and supernatants attaining concentrations ranging from 150 to $300 \mu \mathrm{g}$ of rGPV/L. By flow cytometry analysis, about $30 \%$ of the cells in these populations were shown to express the rGPV in their membrane. Cell populations selected by limiting dilution expressed higher rGPV yields. Mice immunized with S2MtGPV or S2AcGPV derived rGPV were capable of mounting a protective immune response characterized by the synthesis of antibodies reacting against the rabies virus. Immunization led to protection against rabies virus experimental infection in challenge studies.

\section{Conclusion}

The data presented here show that $\mathrm{S} 2$ cells are suitable hosts for the rGPV expression allowing its synthesis in a high degree of physical and biological integrity.

\section{Acknowledgements}

This work was supported in part by grants and scholarships from the FAPESP, CNPq, CAPES and Fundação Butantan. C. A. Pereira is recipient of CNPq research fellowships. We thank M.J.S. Leme for technical assistance performing "in vivo" challenge assays. 


\section{References}

I. Warrel MJ, Warrel DA: Rabies and other lyssavirus diseases. Lancet 2004, 363:959-969.

Publish with Bio Med Central and every scientist can read your work free of charge

"BioMed Central will be the most significant development for disseminating the results of biomedical research in our lifetime. " Sir Paul Nurse, Cancer Research UK

Your research papers will be:

- available free of charge to the entire biomedical community

- peer reviewed and published immediately upon acceptance

- cited in PubMed and archived on PubMed Central

- yours - you keep the copyright

Submit your manuscript here:

http://www.biomedcentral.com/info/publishing_adv.asp 